\section{Antarctic research frozen out of Japan's budget plans}

Keiko Kandachi, Tokyo

Japan's finance ministry is set to pull the plug on a $¥ 40$-billion (US $\$ 360$-million) project to build a research ship for Antarctic exploration.

Ministry officials say that the plan lacks the popular appeal to justify its cost. But Earth scientists contend that the ship is essential to Japan's Antarctic research programme. On 7 November, researchers were joined by a range of celebrities at a rally in Tokyo in support of the project.

The country's current ice-breaking boat, the 21-year-old Shirase, has only about four years of working life left, researchers argue. But the finance ministry is reluctant to fund a replacement despite pleas from the Council for Science and Technology Policy, Japan's highest science-policy body, which restated its support for the ship on 17 October.

Finance-ministry officials say that next year's budget, to be announced next month, is unlikely to include initial funding for the ship. "We don't think the Antarctic programme has the nation's understanding and support to justify the large budget," says Hideaki Imamura, deputy budget director at the finance ministry.

Other projects, such as the $¥ 60$-billion Earth-drilling ship, Chikyu, which is currently under construction, seem to have overstretched the resources available for ocean research in Japan.

Loss of the ice-breaker would impair international research in Antarctica, says Chris Rapley, director of the British Antarctic Survey. Even a delay would damage programmes that depend on continuously collected data, says Okitsugu Watanabe, director-general of the National Institute of Polar Research in Tokyo. But he concedes that Japanese Antarctic research could continue without the new ship. "We could negotiate to use ships from other countries," he says.

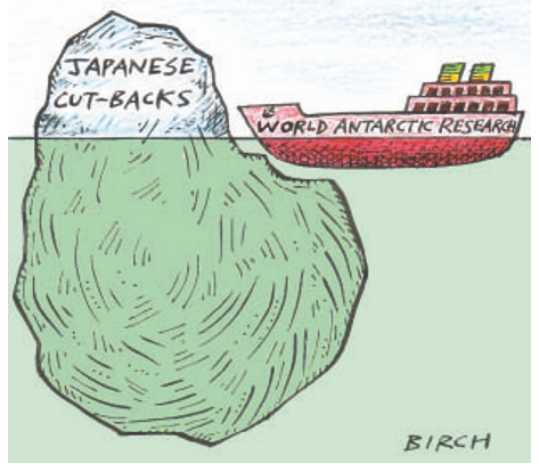

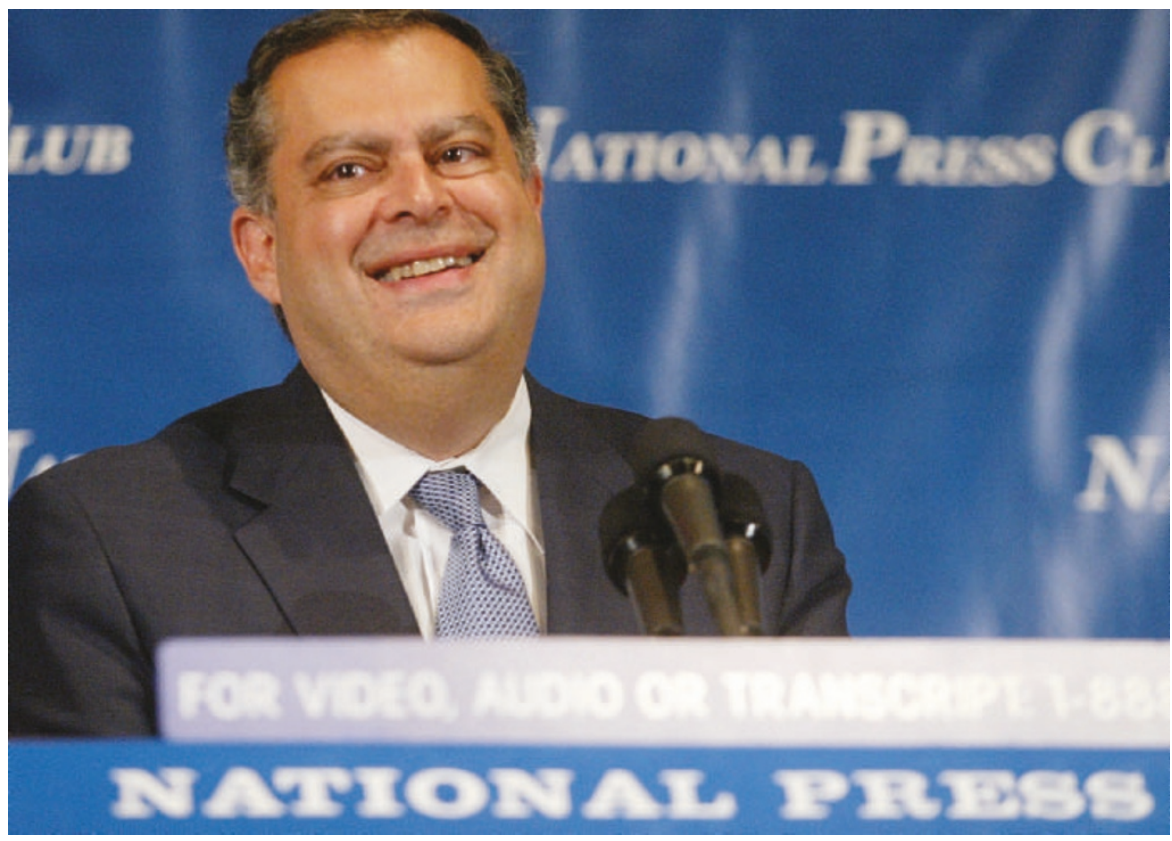

Future view: Spencer Abraham reveals a list of the 28 facilities that US researchers need the most.

\title{
US reveals physics wish-list in bid for scientific frontier
}

\section{Geoff Brumfiel, Washington}

It must have felt as though Christmas had come early for US physicists this week, when the Department of Energy announced a list of 28 scientific facilities that it wants to build in the next 20 years. But it remains to be seen if the department's Office of Science can raise the billions of dollars needed to complete the projects.

At the top of the department's near-term priorities is the international fusion project, ITER, which the United States rejoined this year. Next is a proposal for a major scientific computing facility, to house supercomputers more powerful than anything currently available for non-military research. Then - equally ranked - come a rare-isotope accelerator, a satellite to probe the Universe's dark energy, a high-power X-ray light source, and a facility that would produce and tag proteins for research worldwide.

"This is our plan to keep the United States at the scientific frontier," says Spencer Abraham, the energy secretary, who announced the wish-list at a 10 November lunch at the National Press Club in Washington DC.

The list — the brainchild of Ray Orbach, head of the Office of Science (see Nature 424, $357-358$; 2003) - is the first of its kind in almost 20 years. A somewhat similar plan was unveiled in the 1980s by Alvin Trivelpiece, then head of the Office of Energy Research. Trivelpiece welcomes the new plan. "It's a well-organized, thoughtthrough proposal," he says.

The plan ranks facilities and upgrades from across the department's laboratories into near, mid- and far-term projects. A US\$6-billion linear collider, to explore particle physics by colliding electrons and positrons, is the top mid-term priority, slated to begin around 2010. The highest-ranked far-term priorities include a US $\$ 400$-million upgrade to the National Synchrotron Light Source at Brookhaven National Laboratory in New York state and a neutrino beam that would be ten times more intense than anything currently available.

Orbach's office ranked facilities on the list by their scientific merit and their relevance to the energy department's mission, officials say. The result closely mirrors the suggestions of the agency's scientific advisory groups and laboratories, says Martha Krebs, president of the consulting firm Science Strategies in Los Angeles and head of the science office under President Bill Clinton.

Abraham says that he hopes the list will help raise the profile of the agency's science mission among the public and in Congress. "I didn't know the Office of Science as well as I do today," he says, "and I don't think a lot of members of Congress do either."

But physics lobbyists are already worried that few of the plan's projects will come to fruition. "When you have a nation running a deficit of half-a-trillion dollars, it's going to be hard to get anything to increase," says Michael Lubell, a physicist at the City University of New York, and head of public affairs at the American Physical Society. www.er.doe.gov 